\title{
Phleboliths Radiographic Features in Plain Radiographs: Report of Three Cases
}

\author{
Características radiográficas de flebólitos em \\ radiografias bidimensionais: relato de três casos
}

\author{
LUCIANA MUNHOZ \\ Camila Lobato da Silva Costa ${ }^{2}$ \\ EMIKo SAITO ARITA ${ }^{3}$
}

\begin{abstract}
Introduction: Phleboliths are calcified thrombi that may be originated from an injury to a vessel wall or stagnation of peripheral blood flow. They are not usually observed in maxillofacial areas and are often associated with vascular malformations. Plain radiographs, as a panoramic radiograph, can be useful tools to detect phleboliths.

Objective: To report three clinical cases observed in panoramic radiographs.

Case report: In this report, three cases of phleboliths are described, as found in routine radiographs, emphasizing its radiographic features in conventional imaging. When evaluating multiple radiopaque structures, randomly distributed in plain radiographs, dental practitioners should stay tuned to the presence of a phlebolith, particularly when "laminations" can be observed. Plain radiographs have an important role in detecting phleboliths; however, patients should be referred to other more accurate imaging exams.

Key-words: Panoramic radiograph. Oral pathology. Vascular calcification.
\end{abstract}

\section{RESUMO}

Introdução: Flebólitos são trombos calcificados oriundos de lesões na parede de vasos ou de estagnação do fluxo sanguíneo periférico. Eles não são normalmente observados na região maxilofacial e com frequência estão associados a malformações vasculares. As radiografias bidimensionais, como a panorâmica, podem ser ferramentas úteis na detecção dos referidos flebólitos.

Objetivo: Relato de três casos clínicos observados em radiografias panorâmicas.

Relato de casos: São aqui descritos três casos de flebólitos, encontrados incidentalmente em radiografias convencionais de rotina, enfatizando-se suas características radiográficas. Ao avaliar múltiplas estruturas radiopacas, distribuídas aleatoriamente em radiografias simples, os cirurgiões-dentistas devem ficar atentos para a presença de um flebólito (estrutura radiopaca geralmente de forma oval), mais facilmente caracterizado quando nele forem observadas "laminações". Apesar das radiografias bidimensionais terem um papel importante na detecção de flebólitos, os casos de pacientes com tal suspeita devem sempre ser encaminhados para investigação mais aprofundada, inclusive por meio de exames de imagem mais precisos.

Palavras-chave: Radiografia panorâmica. Patologia oral. Calcificação Vascular.

\footnotetext{
${ }^{1}$ Mestranda em Diagnóstico Bucal, Departamento de Estomatologia, Faculdade de Odontologia da Universidade de São Paulo.

${ }^{2}$ Especialista em Radiologia e Imaginologia Odontológica pela Fundação para o Desenvolvimento Científico e Cultural da Odontologia (FUNDECTO), conveniada à Faculdade de Odontologia da Universidade de São Paulo.

${ }^{3}$ Professora Doutora Assistente, Departamento de Estomatologia, Faculdade de Odontologia da Universidade de São Paulo.
} 


\section{INTRODUCTION}

Phleboliths are usually found in the pelvic veins $^{1}$ and can occur within the intestine, uterine and prostatic veins; notwithstanding, they are not frequent in head and neck sites ${ }^{2}$ and rarely found in maxillofacial areas. ${ }^{3,4}$ Phleboliths are often associated with vascular malformations, such a hemangiomas ${ }^{5,6}$ or a venous malformation (VM). ${ }^{7}$ There are only a few cases described in the literature that they are not related to vascular malformations. ${ }^{2}$

Phleboliths are calcified thrombi ${ }^{8}$ and their pathogenesis involves slowing of peripheral blood flow, what may be originated from an injury to a vessel wall or stagnation of the flow of blood, ${ }^{1}$ by trauma ${ }^{7}$ or even by vascular malformations. ${ }^{8}$ The soft tissue calcification due to the deposition of calcium crystals is classified as "dystrophic calcification" 9 and they occur by passive precipitation. ${ }^{10}$

The thrombi, produced by slowing of peripheral blood flow, become organized and mineralized. ${ }^{4,7,11}$ In a first moment of the calcification, it is formed the core of the phlebolith; then, the fibrous component undergoes a secondary calcification and becomes attached. The repetition of this process causes phleboliths enlargement.4,11 The formation of phleboliths is typically asymptomatic. $^{4}$

The mixture of calcium carbonate and calcium phosphate, due to the mineralization process related to phleboliths, ${ }^{4}$ is the reason why phleboliths present mostly radiopaque radiographic images in conventional techniques. They can have radiolucent or radiopaque core and, due the different moments of calcification of the thrombus, they have an appearance of concentric rings, also denominated "laminations". ${ }^{12}$ In the maxillofacial area they are frequently oval, with variable size ${ }^{7}$ commonly multiple ${ }^{12}$ and can be usually found on routine radiographs, in cases frequently diagnosed as hemangiomas or vascular malformations, $, 8,13,14$ although they can also be found in regions submitted to physical traumatism. ${ }^{15}$

Despite of the use of plain radiographs as a complementary tool to diagnose phleboliths, they can be better detected in computed tomography, ${ }^{8,13}$ which can clearly show calcified and/or hyper attenuated structures, as draining veins and dilated arterial feeders. ${ }^{16}$ Magnetic Resonance Imaging can provide the best view of surrounding soft tissue and the extent of the lesion related to phleboliths formation. ${ }^{12,17}$

In the present report, three cases of phleboliths (found in routine radiographs) are described, emphasizing the importance of radiographic features in conventional imaging.

\section{Case Reports}

\section{Case histories and clinical findings}

Three Caucasian female patients (40, 42 and 46 years old, respectively) were referred to a private Dental Radiologic Clinic, for radiographic exams, with the purpose of planning oral rehabilitation. At the moment of evaluation, the patients did not report any clinical symptoms, nor showed any clinical signs of intraoral or extraoral alterations, except for case 3. So, medical history did not provide relevant information for case 1 and case 2 patients.

\section{IMAGING EVALUATIONS}

\section{Case 1}

The panoramic radiograph showed the absence of some teeth, alveolar bone loss and cavities. In the right side of the patient, overlapping and located inferiorly to the angle of the mandible, it was observed multiple radiopaque oval-shaped structures, with 
different sizes, randomly distributed. The phleboliths characteristic formation in multiple moments can be evidenced by the distribution "in lamella" of the radiopaque areas (Figure 1). The lateral cephalometric radiograph also showed the radiopaque areas (Figure 2), but they were better detailed in panoramic technique.

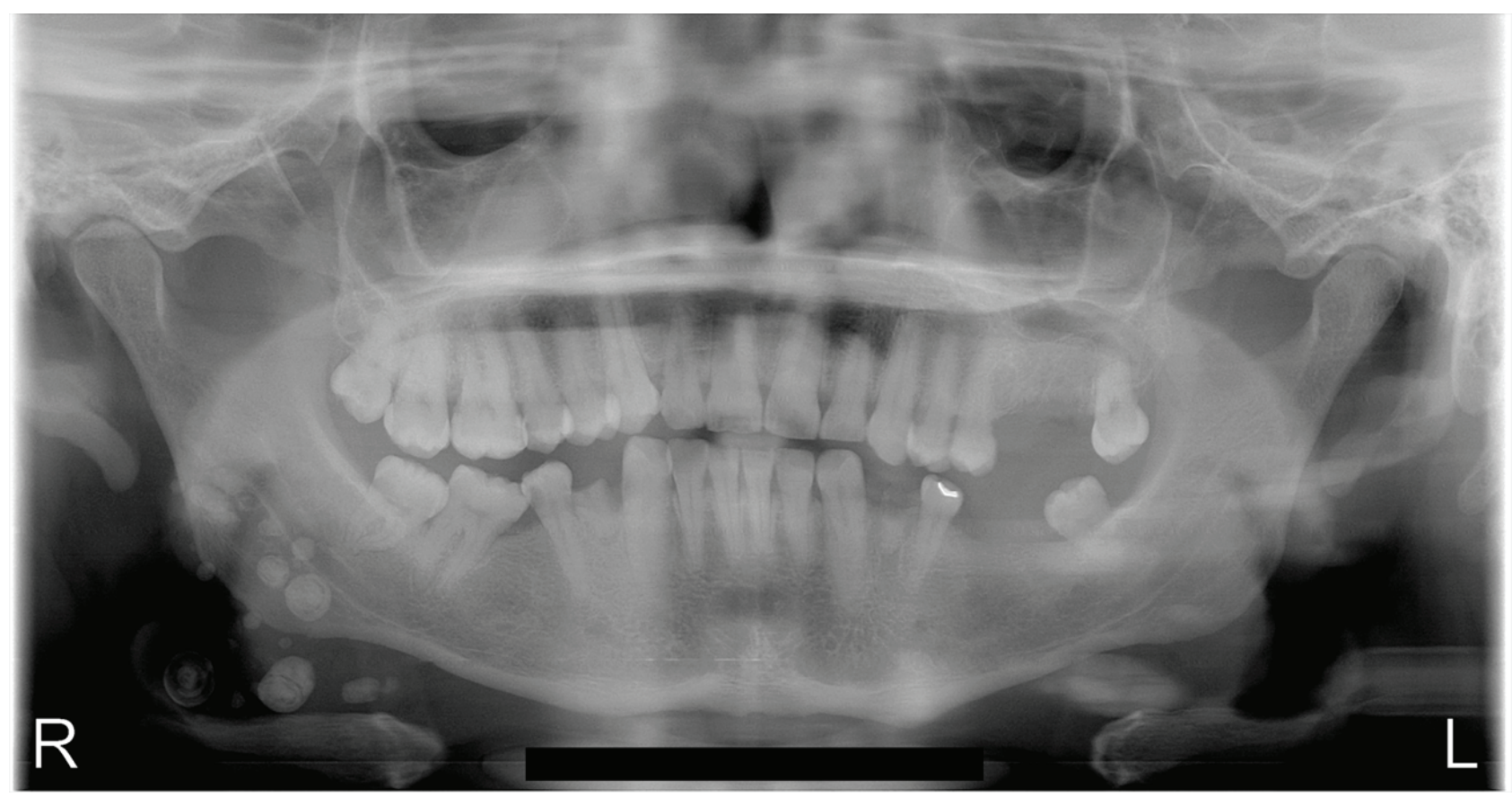

Figure 1: Panoramic radiograph of case 1.

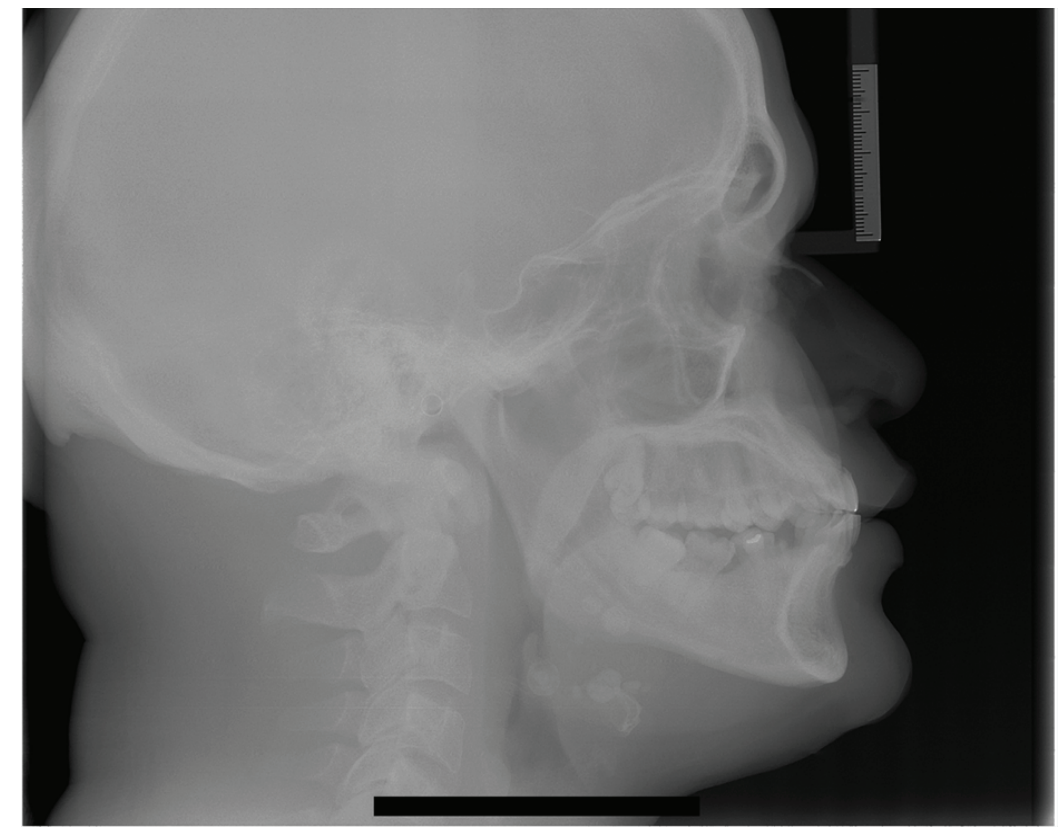

Figure 2: Lateral cephalometric radiograph of case 1. 


\section{Case 2}

In this case, the panoramic radiograph also evidenced the absence of some teeth, alveolar bone loss and cavities (Figure 3). At the right side of the patient, overlapping the ramus of the mandible, it was observed multiple radiopaque oval-shaped structures, with different sizes, more discreet and smaller than in case 1.

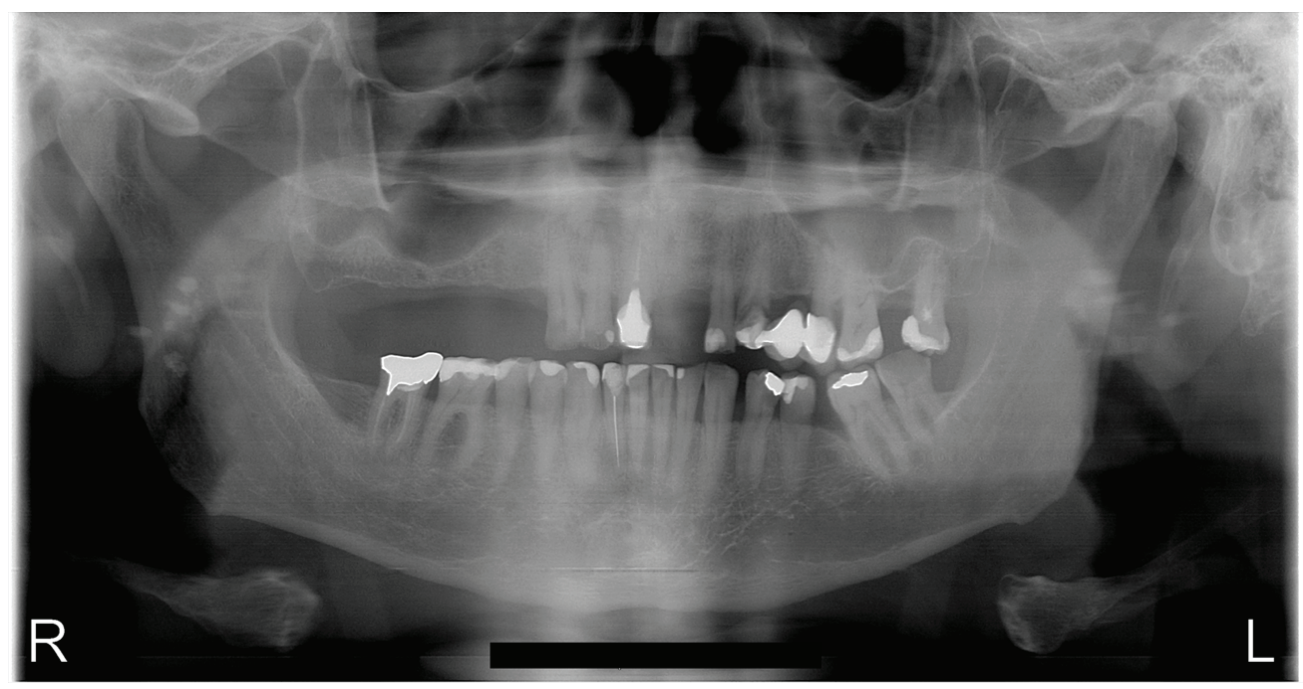

Figure 3: Panoramic radiograph of case 2.

\section{Case 3}

The panoramic radiograph showed multiple oval-shaped radiopaque structures on the right side of the patient, both overlapping as located near the mandible angle and cervical vertebrae, randomly distributed (Figure 4). Extraoral examination showed a blue-purple swelling on the right side of the face. The patient said that the swelling had been present since birth and had grown as she aged, with a previous diagnosis of facial VM. Despite of the evident swelling, the patient declared that it was painless.

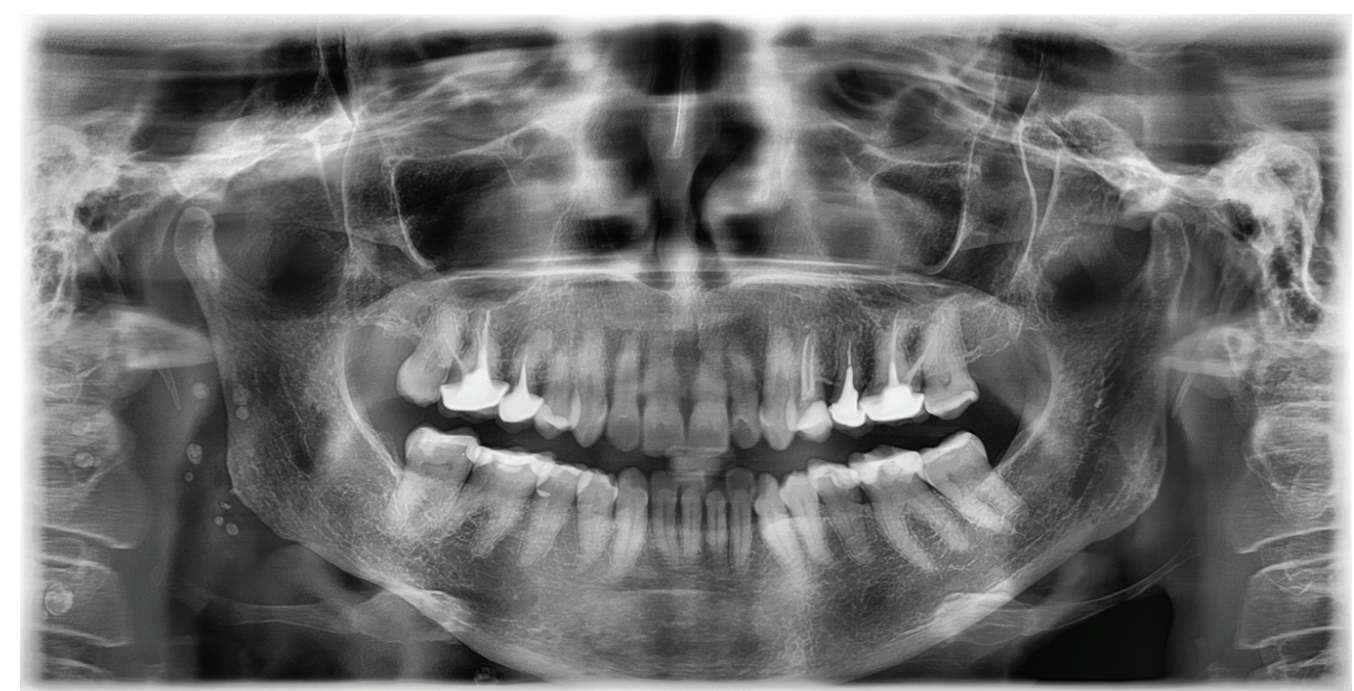

Figure 4: Panoramic radiograph of case 3. 


\section{Discussion}

Phleboliths are incidental findings in routine radiographic examinations, mostly due to the subjective or lack of symptoms. Conventional radiographs, such as panoramic, are helpful to detect phleboliths, ${ }^{13,18}$ although they have some limitations, mainly due to structure overlaps. ${ }^{13}$

In maxillofacial area, phleboliths usually present theirselves as multiples oval-shaped radiopaque structures, randomly distributed and varying in size. ${ }^{7}$ They may be associated with intramuscular hemangiomas $(\mathrm{IH})$ or VMs. ${ }^{7}$ Plain radiographs have limited role in the investigations of $\mathrm{IHs}$ and VMs, because they can identify just calcified thrombi; ${ }^{18}$ otherwise, they can be convenient to detect asymptomatic vascular alterations, as presented in cases 1 and 2. In panoramic radiographs, the masseter muscle is superimposed to mandible angle and ramus, and a calcified thrombus from an $\mathrm{IH}$ related to this muscle might be located in the same area, as showed in cases 1 and 2. After the detection of the phleboliths, the patients of cases 1 and 2 had been referred for further investigations and appropriate medical treatment.

Case 3 had already the diagnosis of $\mathrm{VM}$, which are part of a spectrum of vascular malformations ${ }^{19}$ and are defined as malformations comprised of slow-flowing in abnormal dilated veins. ${ }^{20}$ VMs are present at birth, as a result of a congenital error of vascular morphogenesis that occurs in intrauterine life,$^{21}$ and grow as the patient ages, in proportion to the somatic growth. ${ }^{19}$ One of the main provisional diagnostic hypothesis in cases 1 and 2 was $\mathrm{IH}$. About $15 \%$ to $25 \%$ of $\mathrm{IH}$ can exhibit phleboliths ${ }^{22}$ and the masseter muscles represent a frequent location of head and neck Ins. ${ }^{23,24}$ VM treatment in maxillofacial area is complicated and has a high recurrence rate..$^{13}$

Nevertheless, the diagnosis of phleboliths in the maxillofacial area demands their differentiation from other calcifications that may take place in this area. The diagnostic hypothesis may strongly include tonsiloliths and healed acne lesions, ${ }^{7}$ specially when are present multiple radiopaque structures. A typical feature of phleboliths is that they are often laminated, with concentric rings, in despite of small phleboliths may present only as a radiopaque structure ${ }^{25}$ and this characteristic may be useful to differ them from other entities. Other hypothesis might be considered, as described in literature, such as sialoliths in the parotid gland, ${ }^{26}$ plaques in the carotid artery, cysticercosis, calcified lymph nodes $^{7}$ and traumatic myositis ossifications. ${ }^{27}$

\section{Conclusions}

In conclusion, when evaluating multiple radiopaque structures randomly distributed in plain radiographs, dental practitioners should stay tuned to the presence of a phlebolith, particularly when "laminations" can be observed. Furthermore, a detailed interview of the patient medical history may help to acure the diagnostic hypothesis. In spite of plain radiographs have an important role in detecting phleboliths, patients should be referred to other more accurate imaging exams.

\section{Conflict of InTERest}

The authors declare that they don't have any conflict of interest.

\section{References}

1. Shemilt $\mathrm{P}$. The origin of phleboliths. $\mathbf{B r} \mathbf{J}$ Surg. 1972, 59 (9): 695-700.

http://onlinelibrary.wiley.com/doi/10.1002/ bjs.1800590903/full

2. Kato H., Ota Y., Sasaki M., Arai T., Sekido Y., Tsukinoki K. A phlebolith in the anterior portion of the masseter muscle. Tokai J Exp Clin Med, 2012; 37 (1): 25-9.

https://www.ncbi.nlm.nih.gov/pubmed/22488560 
3. Ikegami N., Nishijima K. Hemangioma of the buccal pad with phlebolithiasis: report of a case. Acta Med Okayama, 1984, 38 (1): 79-87. https://www.ncbi.nlm.nih.gov/pubmed/6702488

4. Sano K., Ogawa A., Inokuchi T., Takahashi H., Hisatsune K. Buccal hemangioma with phleboliths. Report of two cases. Oral Surg Oral Med Oral Pathol, 1988; 65 (2): 151-156.

tps://www.ncbi.nlm.nih.gov/pmc/articles/ PMC4456754/

5. Mandel L. Intramuscular hemangioma with phleboliths or choristoma? J Oral Maxillofac Surg, 2001, 59 (12): 1.511-1.512. https://www.ncbi.nlm.nih.gov/pubmed/11732048

6. Osada K., Yoshihara T., Itoh M. [Intramasseter hemangiomas: a case report]. J Otolaryngol, 2000, 29 (3): 166-169.

https://www.ncbi.nlm.nih.gov/pubmed/10883831

7. Mandel L., Perrino MA. Phleboliths and the vascular maxillofacial lesion. J Oral Maxillofac Surg, 2010, 68 (8): 1973-1976.

https://www.ncbi.nlm.nih.gov/pubmed/20542619.

8. Altuğ HA, Büyüksoy V., Okçu KM, Doğan $N$. Hemangiomas of the head and neck with phleboliths: clinical features, diagnostic imaging, and treatment of 3 cases. Oral Surg Oral Med Oral Pathol Oral Radiol Endod, 2007, 103 (3): e 60-64.

https://www.ncbi.nlm.nih.gov/pubmed/17188913

9. Mignemi NA, Yuasa M., Baker CE, Moore SN, Ihejirika RC, Oelsner WK, et al. Plasmin Prevents Dystrophic Calcification After Muscle Injury. J Bone Miner Res, 2017, 32 (2): 294-308. ttps://www.ncbi.nlm.nih.gov/m/pubmed/27530373/

10. Doherty TM, Asotra K., Fitzpatrick LA, Qiao JH, Wilkin DJ, Detrano RC, et al. Calcification in atherosclerosis: bone biology and chronic inflammation at the arterial crossroads. Proc Natl Acad Sci U S A, 2003, 100 (20): 11.201-11.206. https://www.ncbi.nlm.nih.gov/pmc/articles/ PMC208734/

11. Raymond AK, Batsakis JG. Angiolithiasis and sialolithiasis in the head and neck. Ann Otol Rhinol Laryngol, 1992, 101 (5): 455-457. https://www.ncbi.nlm.nih.gov/pubmed/1570941

12. Zengin AZ, Celenk P., Sumer AP. Intramuscular hemangioma presenting with multiple phleboliths: a case report. Oral Surg Oral Med Oral
Pathol Oral Radiol, 2013, 115 (1): e 32-36.

https://www.ncbi.nlm.nih.gov/pubmed/23217548

13. Orhan K., Icen M., Aksoy S., Avsever H., Akcicek $\mathrm{G}$. Large arteriovenous malformation o the oromaxillofacial region with multiple phleboliths.

Oral Surg Oral Med Oral Pathol Oral Radiol, 2012, 114 (4): e 147-158.

https://www.ncbi.nlm.nih.gov/pubmed/22986253

14. Mulliken JB, Fishman SJ, Burrows PE. Vascular anomalies. Curr Probl Surg., 2000, 37 (8): 517-584.

https://www.ncbi.nlm.nih.gov/pubmed/10955029

15. Gouvêa Lima GeM, Moraes RM, Cavalcante AS, Carvalho YR, Anbinder AL. An Isolated Phlebolith on the Lip: An Unusual Case and Review of the Literature. Case Rep Pathol., 2015, 2015: 507840.

https://www.ncbi.nlm.nih.gov/pubmed/26266070

16. Mossa-Basha M., Chen J., Gandhi D. Imaging of cerebral arteriovenous malformations and dural arteriovenous fistulas. Neurosurg Clin $\mathbf{N}$ Am., 2012, 23 (1): 27-42.

https://www.ncbi.nlm.nih.gov/pubmed/22107856

17. Kanaya H., Saito Y., Gama N., Konno W., Hirabayashi $\mathrm{H}$., Haruna S. Intramuscular hemangioma of masseter muscle with prominent formation of phleboliths: a case report. Auris Nasus Larynx, 2008, 35 (4): 587-591.

https://www.ncbi.nlm.nih.gov/pmc/articles/ PMC4298281/

18. Lowe LH, Marchant TC, Rivard DC, Scherbel AJ. Vascular malformations: classification and terminology the radiologist needs to know. Semin Roentgenol., 2012, 47 (2): 106-117. https://www.ncbi.nlm.nih.gov/pubmed/22370189

19. Chava VR, Shankar AN, Vemanna NS, Cholleti SK. Multiple venous malformations with phleboliths: radiological-pathological correlation. J Clin Imaging Sci., 2013, 3 (Suppl 1): 13.

http://www.clinicalimagingscience.org/article. asp? issn=2156-7514; year=2013; volume $=3$;iss ue $=2 ;$ spage $=13$; epage $=13$; aulast $=$ Chava

20. Dubois J., Soulez G., Oliva VL, Berthiaume MJ, Lapierre C., Therasse E. Soft-tissue venous malformations in adult patients: imaging and therapeutic issues. Radiographics., 2001, 21 (6): 1.519-1.531.

https://www.ncbi.nlm.nih.gov/pubmed/11706222 
21. LM, Richter GT, Suen JY. Diagnosis and management of hemangiomas and vascular malformations of the head and neck. Oral Dis., 2010, 16 (5): 405-418.

ttps://www.ncbi.nlm.nih.gov/pmc/articles/ PMC4700245/

22. Morris SJ, Adams H. Case report: paediatric intramuscular haemangiomata--don't overlook the phlebolith! Br J Radiol., 1995, 68 (806): 208-211.

https://www.ncbi.nlm.nih.gov/pubmed/7735755

23. Alami B., Lamrani Y., Addou O., Boubbou M., Kamaoui I., Maaroufi M., et al. Presumptive intramuscular hemangioma of the masseter muscle. Am J Case Rep., 2015, 16: 16-19. https://www.ncbi.nlm.nih.gov/pmc/articles/ PMC4298281/

24. Rossiter JL, Hendrix RA, Tom LW, Potsic WP. Intramuscular hemangioma of the head and neck. Otolaryngol Head Neck Surg., 1993, 108 (1): 18-26.

https://www.ncbi.nlm.nih.gov/pubmed/8437870
25. Su YX, Liao GQ, Wang L., Liang YJ, Chu M., Zheng GS. Sialoliths or phleboliths? Laryngoscope., 2009, 119 (7): 1.344-1.347.

h t t p s: / / w w w.n c bi.n I m.nih.gov/ pubmed/19507216

26. Oh HK, Park HJ, Oh JS, Jung S., Kook MS. Transcutaneous approach for the removal of parotid gland stones. J Craniofac Surg. 2014, 25 (6): 2.196-2.198.

https://www.ncbi.nlm.nih.gov/pub$\mathrm{med} / 25318444$

27. Torres-Lagares D., Barranco-Piedra S., Serrera-Figallo MA, Hita-Iglesias P., Martínez-Sahuquillo-Márquez A., Gutiérrez-Pérez JL. Parotid sialolithiasis in Stensen's duct. Med Oral Patol Oral Cir Bucal., 2006, 11 (1): E 80-84. https://www.ncbi.nlm.nih.gov/pubmed/16388301

Submetido em: 6-9-2017

Aceito em: 15-1-2018 